\title{
Differences in Wage Growth by Education Level Do Less-Educated Workers Gain Less from Work Experience?
}

\author{
Helen Connolly and Peter Gottschalk*
}

August 2006

\begin{abstract}
This paper revisits the old question of whether wage growth differs by education level. Do more educated workers invest more than less educated workers in firm specific, sector specific or general human capital? Do they gain more from improved job match? The paper makes both a methodological and a substantive contribution by offering an alternative strategy for separately identifying returns to general experience, sector specific experience, firm tenure, and job match. Our empirical results, based on the Survey of Income and Program Participation, show that overall wage growth is higher for more-educated workers. This reflects higher returns to general experience for college graduates and higher returns to sector experience for high school graduates. Improvements in job match grow monotonically with education.
\end{abstract}

${ }^{*}$ Helen Connolly, Department of Economics, Northeastern University, Boston, MA 02115. Peter Gottschalk, Economics Department, Boston College, Chestnut Hill, MA 02467. This project was funded under a grant from the Russell Sage Foundation. We want to offer special thanks to Steven Haider and Derek Neal for their useful comments. 


\title{
Differences in Wage Growth by Education Level
}

\author{
Do Less-Educated Workers Gain Less from Work Experience?
}

\section{Introduction}

Do less-educated workers invest less in human capital than more-educated workers? The answer to this question is of interest to the academic community as well as the policy community concerned with the causes of low earnings. Heckman et al. (2003) lists three central implications of the basic human capital model developed by Mincer (1974). The first of these implications is that log earnings profiles are parallel across schooling levels. The idea of "parallelism", which is also an implication of the original Ben-Porath (1967) model, reflects Mincer (1974)'s assumption that the proportion of earnings devoted to the production of human capital is the same across education groups. As Heckman et al. (2003) shows, relaxing this assumption allows the slopes of the tenure profiles to differ across education groups.

Differences in the slopes of tenure profiles have important implications both for measurement and for understanding job turnover. Since potential earnings and investment in human capital are not directly observable, one has to make inference about earnings capacity from the level and growth in observed wages. If workers of all education levels invest the same proportion of their earnings capacity into the production of human capital, then earnings profiles are parallel and the gap in observed log earnings between different education groups is equal to the unobserved gap in potential earnings. If, on the other hand, workers with low education invest less in human capital than workers with high education, then the gap in observed earnings understates the gap in earnings capacity, especially early in the life-cycle when the investment occurs. ${ }^{1}$

Lower investment in human capital may also partially explain the higher observed job turnover rates of less-educated workers. If less-educated workers invest less in firm-specific human capital, then they have less to lose by leaving their current employer. As a result they have a lower reservation value for accepting an alternative offer. A corollary to this is that a higher proportion of the wage gains of less-educated workers will come from between-job wage growth (which reflects improved job match) instead of within-job wage growth (which is assumed to reflect returns to human capital).

This paper presents new evidence on the relationship between education and wage growth. Our use of longitudinal data that identifies transitions to new employers allows us to separately identify differences across education groups in returns to firm tenure, sector-specific experience, general experience, and improved job match. While the focus of the paper is on the substantive issues discussed earlier, we provide a modification of the Topel (1991) estimator which identifies all parameters of the model and is easily implemented.

The remainder of this paper is divided into five sections. Section 2 reviews the substantive literature on differences in wage growth by education level, as well as the methodological literature on estimating returns to human capital when tenure and sector-specific experience

\footnotetext{
${ }^{1}$ This point is stressed in Heckman et al. (1998).
} 
are not independent of the unobserved job match component. Section 3 presents the econometric framework. Section 4 discusses our data and Section 5 provides the results. The final section summarizes our findings.

\section{Literature Review}

Our study contributes to two bodies of literature. The first is the substantive literature on sources of wage growth and how these differ by education level. The second is the methodological literature on estimating the sources of wage growth when tenure and sectorspecific experience are potentially endogenous.

The literature documenting differences in wage growth by skill groups can usefully be subdivided into three types of studies: cross-sectional studies by education group; longitudinal studies by education group; and longitudinal studies of welfare recipients.

The earliest studies only had access to cross-sectional data. Mincer (1974), using the 1960 Census of Population, finds that more-educated workers have flatter log wage profiles than the less-educated, but that the negative interaction between education and experience is not statistically significant for weekly wages. Heckman et al. (2003) updates this early work using nonparametric matching regressions to estimate the slopes of log annual earnings in the 1940 to 1990 Censuses. The authors find that they can reject parallel earnings profiles after the 1960 Census though not before. Murphy and Welch (1992) and Lemieux (2003), using Current Population Survey (CPS) data, find similar returns to experience through the mid-1980s, with less-educated workers experiencing a steepening of their profiles in the later part of the decade. ${ }^{2}$ However, Card and DiNardo (2002), also using the CPS, shows that this was a temporary change and that the experience profiles of male high school graduates flattened relative to those of college graduates during the 1990s. ${ }^{3}$ For females, profiles also flattened for less-educated workers and steepened for more-educated workers, resulting in substantially flatter profiles for females with 12 years of education compared to females with 16 years of education by the late-1990s.

While these cross-sectional studies offer useful summaries, they do not differentiate between wage growth while working for the same employer from changes that occur when respondents move to new jobs. ${ }^{4}$ Mincer and Jovanovic (1981) and Light and McGarry (1998), among others, have found these differences to be quantitatively important. In order to identify the very different processes generating these two sources of wage growth, it is necessary to have access to longitudinal data.

Longitudinal studies of differences in wage growth by education are relatively rare. Heckman et al. (1998) uses the National Longitudinal Survey of Youth (NLSY) to estimate the underlying parameters of a generalized human capital model for white males. The authors find that more-educated workers invest a higher proportion of their earnings capacity into

\footnotetext{
${ }^{2}$ In Figure IIb of Murphy and Welch (1992), returns to experience are measured by the ratio of workers with 26 to 35 years of experience to workers with 1 to 10 years of experience.

${ }^{3}$ This conclusion is based on a comparison of $\log$ wages at 2, 10, and 30 years of potential experience (from Figures 14 and 15 in Card and DiNardo (2002)).

${ }^{4}$ As is well known, another drawback of cross-sectional profiles is that they do not trace out the longitudinal profiles relevant to human capital or matching models of wage growth.
} 
the further production of human capital. This translates into higher wage growth for moreeducated white males, though the differences are quantitatively small. Gladden and Taber (2000) uses the NLSY to estimate experience profiles for high school graduates and high school dropouts using potential experience as an instrument for observed experience. The authors find that working high school dropouts have somewhat steeper profiles than workers with a high school degree. Their focus on the difference between high school graduates and high school dropouts, however, does not allow a comparison of these groups with college graduates. Dustmann and Meghir (2005) also estimate sources of wage growth for German workers with and without apprenticeship training.

The third group of studies on differentials in wage growth focuses on welfare recipients (another group with relatively low skills) rather than differences across education groups. While these studies do not include an explicit comparison group and do not identify the sources of wage growth, they offer useful auxiliary evidence on wage growth for a disadvantaged group. These studies uniformly find low wage growth for working welfare recipients. Burtless (1995) finds that former welfare recipients experience less than a one percent per year growth in wages over a ten-year period. Card et al. (1999) also finds low wage growth (1.6 to 2.6 percent per year) for a set of long-term welfare recipients in Canada. Likewise, the experimental evidence reviewed in Gueron and Pauly (1991) indicates that there are only modest increases in earnings from job placements, with most of the gains coming from increases in hours worked, not higher wage rates. ${ }^{5}$ While Moffitt and Rangarajan (1991) focuses on female heads of household with children under 18 rather than on welfare recipients, the authors also find that wages increase only by two percent per year for this group of workers.

We go beyond this previous literature by explicitly modeling returns to tenure, sectorspecific experience, general experience, and job match by education group. This allows us to compare differences across education groups in the sources of growth, as well as differences in overall growth.

The second major branch of the literature relevant to this study focuses on identification and estimation of returns to tenure, sector-specific experience, general experience, and improved job match. This literature deals with the inherent problem that the job match component in a standard log wage equation may be correlated with tenure, sector-specific experience, or general experience. Agents with longer tenure have more to give up when moving to a new job since they lose the returns to human capital that are specific to their current employers. They also lose returns to sector-specific skills if the new job is in a different sector. Therefore, agents require a higher job match component in order to compensate for lost returns to firm-specific tenure or sector-specific experience. This introduces a positive correlation between the unobserved match component and the observed job tenure and sector experience in a standard log wage equation. The matching process may also introduce a correlation between the job match component and general experience since workers with more labor market experience have had a longer time to find good matches.

Dustmann and Meghir (2005) and Neal (1995), address this endogeneity issue by using data sets that include plant closings as the exogenous source of variation in tenure and sector-specific experience. Alternative approaches initially developed in Altonji and

\footnotetext{
${ }^{5}$ See Table 1.1 of Gueron and Pauly (1991).
} 
Shakotko (1987) and Topel (1991) are applicable to a wider set of data sets without such rich data on plant closings. The Altonji and Shakotko IV estimator has been used to estimate returns to tenure and experience in Altonji and Williams (1997), Altonji and Williams (1998), and others. It has recently been expanded in Kambourov and Manovskii (2005) and Parent (2000) to include the effects of sector-specific experience. However, as Kambourov and Manovskii (2005), Parent (2000), and Pavan (2005) show, the introduction of sectorspecific experience introduces additional sources of potential endogeneity that may violate the necessary identifying assumptions for the Altonji and Shakotko IV estimator.

We offer an alternative estimator by modifying the procedure developed in Topel (1991). Our modified procedure not only allows for sector-specific experience, but also identifies all the parameters of the model, which was not possible in the original Topel estimator. We start by using the standard search framework initially proposed by Burdett (1978) to develop identifying restrictions. We show that the expected value of the job match component increases with tenure and sector-specific experience, but does not increase with general experience when the agent searches while on the job. Instead, the expected value of the match component changes discretely when an offer is accepted, rather than increasing continuously with experience. ${ }^{6}$ We then distinguish between on-the-job search and search while not employed. This imposes additional identifying restrictions. We show that while the original Topel estimator identified returns to tenure and returns to general experience up to an additive constant, the modified procedure identifies all parameters, including returns to sector-specific experience.

\section{Identification and Estimation}

In this section, we start by presenting the empirical framework initially used by Altonji and Shakotko (1987) and Topel (1991) to estimate returns to tenure and general experience and augmented in Kambourov and Manovskii (2005), Parent (2000), and others to include returns to sector-specific experience. ${ }^{7}$ We then show how this empirical framework can be recast in terms of a simple search framework. In the following section, we use the implications of this search framework to modify and extend Topel's estimator.

\subsection{Empirical Framework}

The following standard log wage model with person-specific and match-specific error components forms the explicit or implicit basis for many of the empirical models in this

\footnotetext{
${ }^{6}$ This specification is consistent with the early work of Mincer and Jovanovic (1981) and the more recent study by Light and McGarry (1998), who both include the number of previous transitions in the wage equation.

${ }^{7}$ Sector-specific experience is transferable to other jobs in the same sector but not to jobs in other sectors. For example, sectors may be defined in terms of industry or occupation.
} 
literature: ${ }^{8}$

$$
\begin{aligned}
Y_{i j t} & =\beta_{X} X_{i j t}+\beta_{T} T_{i j t}+\beta_{S} S_{i j t}+\varepsilon_{i j t} \\
\varepsilon_{i j t} & =\phi_{i j t}+\mu_{i}+v_{i j t}
\end{aligned}
$$

where $Y_{i j t}$ is log wages, $X_{i j t}$ is general labor market experience, $S_{i j t}$ is sector-specific experience, and $T_{i j t}$ is tenure for person $i$ in job $j$ in period $t . \mu_{i}$ is a person-specific error component and $\phi_{i j t}$ is a job match component given by:

$$
\phi_{i j t}=\alpha_{0}+\alpha_{X} X_{i j t}+\alpha_{T} T_{i j t}+a_{S} S_{i j t}+\eta_{i j t}
$$

Equation (3) is motivated in the literature as a linear approximation to a matching process. ${ }^{9}$ Tenure is included in equation 3 since workers are assumed to stay longer in jobs with a high match component. Hence the expectation of match quality increases the longer the person has been in job $j$. Likewise, if good matches lead to long tenure in the same sector then the expectation of match quality increases with sector experience. The expected value of the job match component is also assumed to increases with general experience. The rationale given in the literature for including experience in equation 3 is that more experienced workers have sampled a larger number of job offers. ${ }^{10}$

Topel (1991) initially used this framework to motivate his two-stage estimator of $\beta_{X}$ and $\beta_{T} \cdot{ }^{11} \phi_{i j t}$ and $\mu_{i}$ are first-differenced out by using within-job wage growth to estimate $\beta_{X}+\beta_{T}$. In the second stage, Topel (1991) estimates equation (1) using observations for the first period of each job. ${ }^{12}$ Since tenure is zero at the start of each job, tenure does not appear in the second-stage estimator. This procedure yields an estimate of $\beta_{X}+\alpha_{X}$, which can be subtracted from the first-stage estimate of $\beta_{X}+\beta_{T}$ to recover $\beta_{T}-\alpha_{X}$. Thus, returns to tenure and experience are identified up to an additive constant, $\alpha_{X}$. Introducing returns to sector-specific experience, $\beta_{S}$, without imposing additional restrictions leads to further identification issues.

We provide an extension to the Topel estimator that identifies all parameters, including returns to sector-specific experience. In the next section, we show that the additional restrictions needed to identify the parameters are a direct implication of the standard search model initially proposed by Burdett (1978).

${ }^{8}$ Altonji and Shakotko (1987) and Topel (1991) explicitly use this framework, but do not include sectorspecific experience.

${ }^{9}$ Note that while the match component is constant within a job, the expected value of the job match component increases the longer the individual stays in the job. $\phi_{i j t}$ should, therefore, be viewed in this early literature as the expectation, not the realization, of the match component.

${ }^{10}$ See Topel (1991), p. 151, Altonji and Shakotko (1987), p. 440, and Parent (2000), p. 311.

${ }^{11}$ Recall that $\beta_{S}$ was assumed to be zero in this early work.

${ }^{12}$ Topel (1991)'s estimator actually utilizes all observations, but each observation is used to obtain an estimate of starting wages. That is, $Y_{i j 0}=Y_{i j t}-\widehat{B} T_{i j t}$, where $\widehat{B}$ is the sum of returns to tenure and experience $\left(\widehat{\beta_{X}+\beta_{T}}\right)$ obtained from the first-stage estimator. 


\subsection{Search Framework}

Consider Burdett (1978)'s standard search framework in which workers may either search full-time or search while on the job. ${ }^{13}$ An individual entering the labor market must decide whether to accept a job offer with a match component $\phi_{i 1}$ or to pay $C_{i}^{f}$ to continue to search full-time and obtain another draw from $f(\phi)$. If the job is accepted, the worker can continue to search on the job at a cost of $C_{i}^{o}>C_{i}^{f}$. Since expected returns to sector experience and tenure are assumed to be the same across jobs available to persons with the same education, the decision of whether to accept the offer depends only on the intercept of the wage profile, which is determined by the match component. The reservation value for accepting the job and continuing to search on the job, $\phi_{i 1}^{*}$, is determined in the standard way by solving for the reservation value where the marginal cost of additional full-time search is equal to the marginal benefit. The expected value of the match component at the start of the first job is given by:

$$
E\left(\phi_{i 1}\right)=\int_{\phi_{i 1}^{*}} \phi f_{1}(\phi) d \phi
$$

where $f_{1}(\phi)$ is the normalized density function. ${ }^{14}$ Let $\phi_{i 1}$ be the unobserved match component in the accepted job. The worker searches on the job and accepts an offer if the match component in the new job exceeds the current match component plus the lost returns to tenure (on the current job) and the lost returns to sector-specific experience (if the offered job is in a different sector). Therefore, the new job is accepted if:

$$
\phi_{i 2}>\phi_{i 1}+\beta_{T} T_{i 1 t}+\beta_{S}\left(S_{i 1 t}-S_{i 2 t}\right),
$$

where $S_{i 1 t}-S_{i 2 t}$ is the difference between the accumulated sector-specific experience of the current job (job 1) and the offered job (job 2). If the jobs are in the same sector, then this term is zero since the match component does not have to compensate for lost returns to sector-specific experience. The conditional expectation of the match component for a person who moves out of a job with a match component of $\phi_{i 1}$ after working in that job for $\tilde{T}_{i 1}$ periods is given by:

$$
E\left(\phi_{i 2} \mid \phi_{i 1}, \tilde{T}_{i 1}, S_{i 1}, S_{i 2}\right)=\int_{\phi_{i 1}+\beta_{T} \tilde{T}_{i 1}+\beta_{S}\left(S_{i 1}-S_{i 2}\right)} \phi f_{2}(\phi) d \phi>\phi_{i 1},
$$

where $f_{2}(\phi)$ is again the normalized density function. Since $\frac{\partial E\left(\phi_{i 2} \mid \phi_{i 1}, \tilde{T}_{i 1}, S_{i 1}, S_{i 2}\right)}{\partial \tilde{T}_{i 1}}>0$, this leads to the standard prediction that the match component increases with tenure in the previous job.

The expected change in the match component for persons who change jobs after $\tilde{T}_{i 1}$

${ }^{13}$ The only modification we make is to allow wages to grow with tenure and experience, while Burdett (1978) assumes constant wages. The distribution of wage rates in Burdett (1978) is equivalent to the distribution of the match components in our model. These determine the intercepts in our wage functions.

${ }^{14}$ i.e., $f_{1}(\phi)=\frac{f(\phi)}{1-F\left(\phi_{1}^{*}\right)}$. 
periods can be obtained by integrating over all acceptable values of $\phi_{i 1}::^{15}$

$$
E\left(\phi_{i 2}-\phi_{i 1} \mid \tilde{T}_{i 1}, S_{i 1 t}, S_{i 2 t}\right)=\int_{\phi_{i 1}^{*}}\left(E\left(\phi_{i 2} \mid \phi_{i 1}, \tilde{T}_{i 1}, S_{i 1}, S_{i 2}\right)-\phi_{i 1}\right) f_{1}\left(\phi_{1}\right) d \phi_{1}>0 .
$$

The expected change in the match component between jobs $j-1$ and $j$ can be obtained in a similar manner. Since the new match component in job $j$ must be high enough to compensate for lost returns to tenure in job $j-1$ and lost returns to sector-specific experience if the accepted job is in a different sector than the current job, it follows that the expected change in the match component for persons who move directly from one job to the next is positive. Therefore:

$$
\Delta \phi_{i j}=E\left(\phi_{i j}-\phi_{i, j-1} \mid \tilde{T}_{i, j-1}, S_{i j}, S_{i j-1}\right)>0, \text { if } J J=1,
$$

where $J J=1$ indicates a job-to-job transition. This expectation increases in $\tilde{T}_{i, j-1}$ and in $\left(S_{i j-1}-S_{i j}\right)$.

This implies that the expected match component increases when a person goes directly from one job to the next and that the size of the discrete change depends on tenure in the previous job and on the lost accumulated sector-specific experience. This forms the basis of our empirical specification for the change in the match component for job-to-job transitions.

Transitions that include an intervening spell of non-employment have somewhat different implications for estimation. Individuals may experience a spell of non-employment between jobs because they have to leave a job for family reasons, because the job is terminated, or because they quit voluntarily. Without access to the previous job, the individual's search problem reverts to the decision of whether to continue searching while unemployed or to accept an offer and continue searching on the job. The expected match component in the new job is then given by equation (4). Thus, for persons who experience an intervening spell of non-employment between job $j$ and job $j-1$, the expected change in the match component is given by:

$$
\Delta \phi_{i j}=E\left(\phi_{i j}-\phi_{i, j-1}\right)=\int_{\phi_{i 1}^{*}} \phi f_{1}(\phi) d \phi-\phi_{i, j-1}, \text { if } J J=0 .
$$

With an intervening spell of non-employment, the optimal strategy is not affected by the lost returns to tenure in the previous job or lost returns to sector-specific skills. This implies that $\tilde{T}_{i, j-1}$ and $S_{i j}-S_{i j-1}$ do not enter the specification for the change in the match component for transitions through non-employment. The distinction between job-to-job transitions and transitions through non-employment allows us to identify all the parameters of the model.

\subsection{Empirical Specification}

Following the previous literature, we use a linear approximation to equations (7) and (8). The change in the job match component differs for persons who move directly from job to

\footnotetext{
${ }^{15}$ Note that this is the expectation for job changers, which is the relevant concept for our purposes. While the match component is higher in job 2 than in job 1 for workers who change jobs, it is not true that the expected match component for persons in their second jobs is higher than the expected match component for all persons in their first jobs. Since persons are more likely to stay in their initial jobs if they have high initial draws, this means that $E\left(\phi_{i 1} \mid\right.$ stayer $)>E\left(\phi_{i 1} \mid\right.$ mover $)$.
} 
job $(J J=1)$, those who have an intervening non-employment spell $(J J=0)$, and those who remain in their current jobs. The linear approximation is given by:

$$
\Delta \phi_{i j}=\left\{\begin{array}{ll}
\alpha_{1}+\alpha_{T} \widetilde{T}_{i, j-1}+\alpha_{S} \tilde{S}_{i, j-1}+\Delta \eta_{i j}, & \text { if } J J=1 \\
\alpha_{2}+\Delta \eta_{i j}, & \text { if } J J=0 \\
0, & \text { within jobs }
\end{array}\right\},
$$

where $\widetilde{T}_{i, j-1}$ is the total accumulated tenure at the end of job $j-1$ and $\tilde{S}_{i, j-1}$ is the sectorspecific experience that would be lost in moving from job $j-1$ to job $j$. If both jobs are in the same sector then $\tilde{S}_{i, j-1}=0$.

Equation 9 is consistent with the simple model in the previous section. Tenure in the previous job and lost sector-specific experience both affect the growth in the match component for persons who search on the job $(J J=1)$, but not for those who have an intervening spell of non-employment $(J J=0)$. $\alpha_{1}$ captures the expected net increase in the match component (above the lost returns to firm-specific tenure and lost returns to sector-specific skills) for persons who make job-to-job transitions. $\alpha_{2}$ captures the expected increase in the match component for those who have an intervening spell of non-employment. ${ }^{16}$

Rewriting equation (1) in first-differences eliminates $\mu_{i}$ :

$$
\Delta Y=\beta_{X} \Delta X+\beta_{T} \Delta T+\beta_{S} \Delta S+\Delta \phi+\Delta v .
$$

Equations (9) and (10) form the basis of our estimation.

We follow Topel (1991) by using a two-stage estimator. In the first stage, we estimate equation (10) for periods in which the respondent stays in the same job. Since, in this case, $\Delta \phi_{i j}=0$ and $\Delta X_{i j}=\Delta T_{i j}=\Delta S_{i j}=1$, the within-job estimator yields the sum of returns to experience, tenure, and sector: ${ }^{17}$

$$
\begin{aligned}
\Delta Y_{w} & \equiv Y_{i j t}-Y_{i, j, t-1} \\
& =\left(\beta_{X}+\beta_{T}+\beta_{S}\right)+\Delta v_{i j} .
\end{aligned}
$$

Estimating equation (10a) identifies $B \equiv \beta_{X}+\beta_{T} \cdot+\beta_{S}$.

Topel (1991)'s second-stage estimator is based on estimating equation (1) in levels using initial wages, so that tenure is zero. Our procedure is to estimate between-job changes in wages using equation (10), rather than wage levels. This has two advantages: First, time-invariant personal characteristics, $\mu_{i}$ are differenced out. This eliminates a potentially important source of endogeneity. Second, we can use equation (9) directly to identify all the parameters of the model.

Between-job wage growth is given by:

$$
\Delta Y_{b} \equiv Y_{j 0}-Y_{j-1, \widetilde{T}}
$$

\footnotetext{
${ }^{16} \Delta \eta_{i j}$ is consistent with heterogenous growth models. For an example see Haider (2001).

${ }^{17}$ This specification assumes that sector is a firm characteristic, such as industry. We also estimated models in which sector is defined by occupation, so that sector can change while working for the same firm. These models gave very similar results.
} 
where $Y_{j-1, \widetilde{T}}$ is the wage in the last period of job $j-1$. Substituting equation (9) into equation (10) yields between-job wage growth for persons who make job-to-job transitions $(J J=1)$ and those who have an intervening spell of non-employment $(J J=0):{ }^{18}$

$$
\begin{aligned}
\Delta Y_{b} & =\left(\alpha_{1}+\beta_{X}+\beta_{S}\right)+\left(\alpha_{T}-\beta_{T}\right) \widetilde{T}+\left(\alpha_{S}-\beta_{S}\right) \tilde{S}+(\Delta \eta+\Delta v), & & \text { if } J J=1 \\
& =\left(\alpha_{2}+\beta_{X}+\beta_{S}\right)-\beta_{T} \widetilde{T}-\beta_{S} \tilde{S}+(\Delta \eta+\Delta v) & & \text { if } J J=0 .
\end{aligned}
$$

Note that since $\tilde{S}=0$ for persons who stay in the same sector, their between-job wage growth is given by:

$$
\begin{aligned}
\Delta Y_{b} & =\left(\alpha_{1}+\beta_{X}+\beta_{S}\right)+\left(\alpha_{T}-\beta_{T}\right) \widetilde{T}+(\Delta \eta+\Delta v), & & \text { if } J J=1 \\
& =\left(\alpha_{2}+\beta_{X}+\beta_{S}\right)-\beta_{T} \widetilde{T}+(\Delta \eta+\Delta v), & & \text { if } J J=0
\end{aligned}
$$

This structure identifies all parameters of the model. The coefficients on $\widetilde{T}$ and $\tilde{S}$ for persons who search while unemployed $(J J=0)$ identify $\beta_{T}$ and $\beta_{S}$, the lost returns to tenure and the lost sector-specific experience for persons who move to a different sector. The coefficients on $\widetilde{T}$ and $\widetilde{S}$ for those who make job-to-job transitions $(J J=1)$ also include the improved job match necessary to induce these individuals to leave their previous jobs. This identifies $\alpha_{T}$ and $\alpha_{S}$. With $\beta_{T}$ and $\beta_{S}$ identified, equation 10a identifies $\beta_{X}$ and the intercept in equation 12 identifies $\alpha_{1}$ and $\alpha_{2}$.

Our estimation strategy, therefore, identifies all the parameters of the model. It also provides an alternative to the Altonji and Shakotko (1987) estimator which has been used extensively in the recent literature, but requires strong additional identifying assumptions when sector-specific experience is entered in the model. ${ }^{19}$ Finally, the testable implication of our model, that wages increase discretely at job changes $\left(\alpha_{1}>0\right.$ and $\left.\alpha_{2}>0\right)$, is strongly supported in our empirical work.

The estimated model consists of equations (10a) and 12. Since the parameters of interest appear in more than one equation we impose the implied constraints across equations. This model is identified under the assumptions that change in the match-specific component, $\Delta \eta$, and the change in the idiosyncratic component, $\Delta v$, are independent of completed tenure in the prior job, $\widetilde{T}$, and the loss in sector-specific experience, $\widetilde{S}{ }^{20}$ We initially estimate the parameters in equations (10a) and 12 imposing the constraint that the parameters are equal across education groups. We then allow these parameters to vary with educational attainment and test whether these constraints can be rejected.

\section{Data}

We use the 1986 through 1996 panels of the Survey of Income and Program Participation (SIPP) to measure wage growth while working for the same employer and the wage gains

\footnotetext{
${ }^{18} \Delta S=1-\tilde{S}$. If the job is in the same sector, then $\tilde{S}=0$ so $\Delta S=1$. This indicates that the individual gains one period of sector-specific experience even when changing jobs. If the new job is in a different sector, then the returns to the additional period of sector-specific experience in the new sector is offset by the loss in sector-specific experience in the previous job, $\tilde{S}$.

${ }^{19}$ See Kambourov and Manovskii (2005), Parent (2000), and Pavan (2005).

${ }^{20}$ This requires either that $v$ and $\eta$ are serially independent or that decisions to change jobs are not influenced by autocorrelated shocks after controlling for person- and job-specific fixed effects, $\mu_{i}$ and $\phi_{i j}$.
} 
associated with changes in employers. The SIPP was designed to provide continuous monthly information beginning in February 1984. Each SIPP panel consists of a series of nationally representative longitudinal surveys of between 14,000 and 36,700 individuals who are followed for 30 to 48 months, depending on the panel. A new panel was started in February of every year from 1984 through 1993. ${ }^{21}$ The 1996 panel began in April and the individuals were followed for a period of four years. ${ }^{22}$

This data set has substantial advantages over the Panel Study of Income Dynamics (PSID), the primary data source used in previous studies. While the PSID covers a much longer period of time (1968 to the present), it only offers limited information on tenure and wage rates while working for the same employer. ${ }^{23}$ The wage data in the PSID is the most problematic. Annual earnings last year is a mixture of earnings on both the new and old jobs when a job change occurs. The alternative is to use the wage rate at the time of the interview. With annual interviews, however, it is not possible to obtain wage changes for jobs that last less than a year. Measures of tenure in the PSID are also problematic since the questions have changed over time, though recent questions have consistently asked about "tenure with current employer". ${ }^{24}$ Finally wages are available only for heads and wives in the PSID.

The SIPP overcomes these problems by including the key variables necessary to identify when respondents change jobs, giving wage changes both while working for the same employer and when moving to a new employer. Individuals within each panel are interviewed every four months. During these interviews, respondents are asked detailed questions about job and earnings histories that cover the previous four months. Unique codes are assigned to each employer allowing us to identify when respondents change employers.

Respondents are asked both their wage rate and their earnings. ${ }^{25}$ For those who do not report hourly wages, we impute their wage rates by dividing monthly earnings by hours worked per week and weeks worked in each month. ${ }^{26}$ These wages are then deflated using the Consumer Price Index to obtain real hourly wage rates in 2000 dollars for each month. ${ }^{27}$

\footnotetext{
${ }^{21}$ While a panel was initiated in February 1989, the data were folded into the 1988 panel.

${ }^{22}$ We do not use the 1984 and 1985 panels because the monthly school enrollment questions were not asked before the 1986 panel.

${ }^{23}$ Both Altonji and Shakotko (1987) and Topel (1991) were limited to annual data with which to measure wages and tenure.

${ }^{24}$ See Brown and Light (1992) for a discussion of the weakness of the tenure questions in the PSID. Both Topel (1991) and Altonji and Williams (1997) recognize this problem. The PSID started collecting retrospective monthly information on changes in employers in 1988. Altonji and Williams (1997) uses these to determine tenure at each interview. The authors, however, only have wage information at each yearly interview.

${ }^{25}$ Respondents are asked about their wages and employers in the two main jobs they held during the month. We define the job with the highest number of hours as the main job.

${ }^{26}$ Since the number of weeks in a month varies between 4 and 5 this can introduce spurious fluctuations in imputed wage rates. Therefore, if a respondent reports the same earnings and same hours worked in each month covered by the interview, we assume that they also worked the same number of weeks in each month; we divide their monthly wages by 4.33 in each of the four months covered by the interview. We also construct this measure for persons reporting an hourly wage rate and find the correspondence between the reported and calculated wage rate is high.

${ }^{27}$ Consumer Price Index - Urban Wage Earners and Clerical Workers, Series Id CWSR0000SA0, seasonally adjusted U.S. city average of all items, base period January 2000 (http: \\www.bls.gov).
} 
Table 1: Summary Statistics, by gender

\begin{tabular}{|c|c|c|c|c|c|}
\hline & Female & Male & & Female & Male \\
\hline Sample size & & & Characteristics & & \\
\hline Persons & 91,602 & 97,508 & Demographics & & \\
\hline Jobs & 150,035 & 164,175 & Age & $\begin{array}{c}36.0 \\
(.063)\end{array}$ & $\begin{array}{c}35.7 \\
(.063)\end{array}$ \\
\hline Job Transitions & 73,565 & 74,155 & & & \\
\hline $\begin{array}{l}\text { Job-to-Job } \\
\quad \text { voluntary }\end{array}$ & $\begin{array}{r}35,433 \\
5,886\end{array}$ & $\begin{array}{r}42,495 \\
6,343\end{array}$ & Non-white & $\begin{array}{l}.167 \\
(.003)\end{array}$ & $\begin{array}{l}.145 \\
(.003)\end{array}$ \\
\hline involuntary & 784 & 1,423 & Hispanic & $\begin{array}{l}.083 \\
(.002)\end{array}$ & $\begin{array}{l}.107 \\
(.002)\end{array}$ \\
\hline Intervening Non-employment & 38,132 & 31,660 & & & \\
\hline voluntary & 10,130 & 6,121 & Education & & \\
\hline involuntary & 1,763 & 2,397 & $\begin{array}{l}\text { Less Than High School } \\
\text { High School Graduate }\end{array}$ & $\begin{array}{l}.109 \\
.659\end{array}$ & $\begin{array}{l}.145 \\
.607\end{array}$ \\
\hline Person Months & $2,139,785$ & $2,379,300$ & College Graduate & .233 & .248 \\
\hline
\end{tabular}

Standard errors in parentheses.

Our sample includes all males and females with positive weights who were 18 to 55 at some point during the panel. For each person we include all months of employment while not in school. ${ }^{28}$ Months when the respondent is in school are dropped in order not to confound the low wages of students with those of other low-wage respondents.

\subsection{Summary Statistics}

The first panel of Table 1 shows the sample size of our data set, which includes over 91,000 females and 97,000 males. Females are employed in over 150,000 jobs and males are seen in over 164,000 jobs. Both males and females are observed in roughly 74,000 job transitions. For females who changed employers, around 35,000 job switches are job-to-job; for males, the number is close to 42,000 job switches. The opposite is true for job changes that occur after an intervening spell of non-employment. Females go through almost 38,000 non-employment breaks between employment, while males are observed moving through non-employment 32,000 times.

While our sample includes individuals from 18 to 55 years of age, the average age of those observed is $36 .{ }^{29}$ The descriptive statistics on race, ethnicity, and education confirm that our sample is largely representative of the national population on these observed characteristics.

\footnotetext{
${ }^{28}$ In a separate analysis we also exclude left-censored jobs since these oversample long jobs which may, in turn, oversample jobs with high returns to tenure. This smaller sample gives results very similar to those reported here.

${ }^{29}$ All descriptive statistics use sample weights.
} 
Non-whites make up roughly 16 percent of the full sample while Hispanics constitute about 9 percent. White non-Hispanics, then, make up roughly 75 percent of the sample. Approximately 11 percent of the females have less than a high school degree while 23 percent have a college degree or more. Among males, around 15 percent do not have a high school degree and 25 percent have a bachelor degree or more.

Table 2: Job Characteristics, by gender and education

\begin{tabular}{|c|c|c|c|c|c|c|}
\hline & \# Workers & \# Jobs & $\begin{array}{c}\text { Average } \\
\text { Wage } \\
\text { Rate at } \\
\text { Start of } \\
\text { Panel } \\
\end{array}$ & $\begin{array}{c}\text { Average } \\
\text { Experience } \\
\text { at Start of } \\
\text { Panel } \\
\end{array}$ & $\begin{array}{c}\text { Average } \\
\text { Number } \\
\text { of Jobs }\end{array}$ & $\begin{array}{c}\text { Proportion } \\
\text { of Job-to- } \\
\text { Job } \\
\text { Transitions } \\
\end{array}$ \\
\hline \multicolumn{7}{|l|}{$\underline{\text { Female }}$} \\
\hline $\begin{array}{l}\text { Less Than High } \\
\text { School }\end{array}$ & 10,043 & 17,371 & $\begin{array}{r}6.14 \\
(.073)\end{array}$ & $\begin{array}{l}16.82 \\
(.361)\end{array}$ & $\begin{array}{r}1.90 \\
(.041)\end{array}$ & $\begin{array}{r}0.04 \\
(.005)\end{array}$ \\
\hline $\begin{array}{l}\text { High School } \\
\text { Graduate }\end{array}$ & 55,853 & 91,906 & $\begin{array}{r}7.71 \\
(.094)\end{array}$ & $\begin{array}{l}13.28 \\
(.172)\end{array}$ & $\begin{array}{r}1.88 \\
(.027)\end{array}$ & $\begin{array}{r}0.14 \\
(.005)\end{array}$ \\
\hline $\begin{array}{l}\text { College } \\
\text { Graduate }\end{array}$ & 19,386 & 30,462 & $\begin{array}{l}12.13 \\
(.219)\end{array}$ & $\begin{array}{r}9.82 \\
(.276)\end{array}$ & $\begin{array}{r}1.80 \\
(.041)\end{array}$ & $\begin{array}{r}0.27 \\
(.012)\end{array}$ \\
\hline \multicolumn{7}{|l|}{$\underline{\text { Male }}$} \\
\hline $\begin{array}{l}\text { Less Than High } \\
\text { School }\end{array}$ & 13,225 & 24,582 & $\begin{array}{r}7.87 \\
(.155)\end{array}$ & $\begin{array}{l}14.08 \\
(.389)\end{array}$ & $\begin{array}{r}2.24 \\
(.060)\end{array}$ & $\begin{array}{r}0.08 \\
(.008)\end{array}$ \\
\hline $\begin{array}{l}\text { High School } \\
\text { Graduate }\end{array}$ & 56,120 & 96,114 & $\begin{array}{r}9.55 \\
(.128)\end{array}$ & $\begin{array}{l}11.25 \\
(.211)\end{array}$ & $\begin{array}{r}2.17 \\
(.035)\end{array}$ & $\begin{array}{r}0.19 \\
(.007)\end{array}$ \\
\hline $\begin{array}{l}\text { College } \\
\text { Graduate }\end{array}$ & 21,793 & 32,999 & $\begin{array}{l}14.16 \\
(.334)\end{array}$ & $\begin{array}{r}9.16 \\
(.303)\end{array}$ & $\begin{array}{r}1.77 \\
(.040)\end{array}$ & $\begin{array}{r}0.32 \\
(.017)\end{array}$ \\
\hline
\end{tabular}

Standard errors in parentheses.

Table 2 shows the average wage rate in each job and average experience at the start of each panel. It also includes the number of individuals and jobs in each gender/education cell. More-educated individuals are shown to have less experience at the start of the panel than the less-educated, but, on average, have higher starting wages.

In the following section, we present descriptive statistics on wage growth within and between jobs for persons classified by educational attainment. We then turn to educational differences in returns to experience, tenure, and job switching, which are the fundamentals that lie behind differences in wage growth. 


\subsection{Wage Growth Within and Between Jobs}

Table 3 presents the mean within-job wage growth across all person months. These tabulations show that mean within-job wage growth increases with education. The average within-job wage growth of females with a college degree is .27 percent per month (3.3 percent per year). In contrast, less-educated females have a monthly wage growth of only .06 percent per month (.8 percent per year). For males, the corresponding differences across education groups are not as large -2.2 percent per year for those who completed college versus 1.3 percent per year for high school dropouts. Thus, on average, annual wage growth while working for the same employer is over 4 times larger for females with a college degree than for those in the lowest education group; for male, wage growth almost doubles between the lowest and highest education groups.

Table 3: Mean Within-job Wage Growth (log wages), by gender and education

\begin{tabular}{|c|c|c|c|c|}
\hline & \multicolumn{2}{|c|}{ Female } & \multicolumn{2}{|c|}{ Male } \\
\hline & Monthly & Annual & Monthly & Annual \\
\hline Less Than High School & $\begin{array}{r}.0006 \\
(.0004)\end{array}$ & $\begin{array}{r}.0076 \\
(.0050)\end{array}$ & $\begin{array}{r}.0011 \\
(.0004)\end{array}$ & $\begin{array}{r}.0132 \\
(.0044)\end{array}$ \\
\hline High School Graduate & $\begin{array}{r}.0017 \\
(.0002)\end{array}$ & $\begin{array}{r}.0199 \\
(.0020)\end{array}$ & $\begin{array}{r}.0014 \\
(.0002)\end{array}$ & $\begin{array}{r}.0164 \\
(.0020)\end{array}$ \\
\hline College Graduate & $\begin{array}{r}.0027 \\
(.0004)\end{array}$ & $\begin{array}{r}.0327 \\
(.0045)\end{array}$ & $\begin{array}{r}.0018 \\
(.0003)\end{array}$ & $\begin{array}{r}.0220 \\
(.0036)\end{array}$ \\
\hline All groups & $\begin{array}{r}.0018 \\
(.0001)\end{array}$ & $\begin{array}{r}.0217 \\
(.0017)\end{array}$ & $\begin{array}{r}.0014 \\
(.0001)\end{array}$ & $\begin{array}{r}.0173 \\
(.0016)\end{array}$ \\
\hline $\begin{array}{l}\text { \# Individuals } \\
\text { \# Observations }\end{array}$ & $\begin{array}{r}91 \\
1,98\end{array}$ & & $\begin{array}{r}97 \\
2,21\end{array}$ & \\
\hline
\end{tabular}

Standard errors in parentheses.

Table 4 details the average wage gains realized by those who switch jobs. Columns 1 and 3 show the average wage growth that job changers experience when moving directly from one job to another. ${ }^{30}$ For males, these wage increases are large and grow with educational attainment. For females, the wage gains are smaller and do not vary systematically with education.

Columns 2 and 4 of Table 4 show the mean log wage change between the last month of one job and the first month of the following job where the transition was accompanied by

\footnotetext{
${ }^{30}$ It is well known that the selected sample of job changers is not representative of all workers. The means in Table 4, therefore, do not represent the mean wage change that a random worker would experience by changing employers, but rather the expected wage growth conditional on having changed employers.
} 
Table 4: Between-job Wage Growth (log wages), by gender, education, and type of job transition

\begin{tabular}{|c|c|c|c|c|}
\hline & \multicolumn{2}{|c|}{ Female } & \multicolumn{2}{|c|}{ Male } \\
\hline & Job-to-Job & $\begin{array}{c}\text { Intervening } \\
\text { Non- } \\
\text { employment }\end{array}$ & Job-to-Job & $\begin{array}{c}\text { Intervening } \\
\text { Non- } \\
\text { employment }\end{array}$ \\
\hline & (1) & $(2)$ & (3) & $(4)$ \\
\hline Less Than High School & $\begin{array}{r}.0209 \\
(.0114)\end{array}$ & $\begin{array}{c}-.0005 \\
(.0090)\end{array}$ & $\begin{array}{r}.0326 \\
(.0095)\end{array}$ & $\begin{array}{c}-.0366 \\
(.0135)\end{array}$ \\
\hline High School Graduate & $\begin{array}{r}.0226 \\
(.0050)\end{array}$ & $\begin{array}{r}-.0453 \\
(.0063)\end{array}$ & $\begin{array}{r}.0354 \\
(.0049)\end{array}$ & $\begin{array}{r}-.0561 \\
(.0079)\end{array}$ \\
\hline College Graduate & $\begin{array}{r}.0209 \\
(.0142)\end{array}$ & $\begin{array}{r}-.0593 \\
(.0225)\end{array}$ & $\begin{array}{r}.0591 \\
(.0125)\end{array}$ & $\begin{array}{r}-.1288 \\
(.0308)\end{array}$ \\
\hline All groups & $\begin{array}{r}.0228 \\
(.0045)\end{array}$ & $\begin{array}{r}-.0390 \\
(.0054)\end{array}$ & $\begin{array}{r}.0390 \\
(.0041)\end{array}$ & $\begin{array}{r}-.0556 \\
(.0067)\end{array}$ \\
\hline \# Job Transitions & 35,433 & 38,132 & 42,495 & 31,660 \\
\hline
\end{tabular}

Standard errors in parentheses.

an intervening spell of non-employment. ${ }^{31}$ In all cases, movement through non-employment between jobs leads to wage decreases. More-educated workers do better than the loweducated when they go directly from one job to the next. In contrast, the wage cuts are larger for the high-educated when they move through non-employment.

These differences in wage changes between job-to-job transitions and transitions with an intervening spell of non-employment can be incorporated into the conceptual framework developed earlier. Once a person leaves a job, the reservation value for the match component in the new job is no longer affected by the match component in the previous job since the option of staying in that job has been eliminated. As a result, the reservation value for the match component is lower.

Combining within- and between-job wage changes, Table 5 shows the resulting monthly and annual wage growth. For both males and females, wage increases are higher for the

\footnotetext{
${ }^{31}$ While the SIPP does not provide sufficient information to distinguish between voluntary and involuntary separations, the very different wage changes for jobs with an intervening spell of non-employment indicate that these transitions correspond to different processes. Prior to 1996, a topical module administered early in each panel asks the reason for leaving the last job. Since this question covers only one job that often occurred before the start of the panel, there is insufficient information to use this question in the estimation.
} 
most-educated. High-educated females earn an additional 3.2 percent each year, which is 2.0 percentage points more than high school dropouts. For males, the lowest educated gain only 1.6 percent each year, while college graduates earn 2.5 percent more each year.

Table 5: Average Wage Growth (log wages), by gender and education

\begin{tabular}{|c|c|c|c|c|}
\hline & \multicolumn{2}{|c|}{ Female } & \multicolumn{2}{|c|}{ Male } \\
\hline & Monthly & Annual & Monthly & Annual \\
\hline & (1) & (2) & (3) & (4) \\
\hline \multirow[t]{2}{*}{ Less Than High School } & .0010 & .0122 & .0013 & .0155 \\
\hline & $(.0004)$ & $(.0052)$ & $(.0004)$ & $(.0047)$ \\
\hline \multirow[t]{2}{*}{ High School Graduate } & .0016 & .0191 & .0015 & .0181 \\
\hline & $(.0002)$ & $(.0020)$ & $(.0002)$ & $(.0021)$ \\
\hline \multirow[t]{2}{*}{ College Graduate } & .0027 & .0320 & .0021 & .0254 \\
\hline & $(.0004)$ & $(.0044)$ & $(.0003)$ & $(.0036)$ \\
\hline \multirow[t]{2}{*}{ All groups } & .0018 & .0216 & .0016 & .0197 \\
\hline & $(.0001)$ & $(.0017)$ & $(.0001)$ & $(.0016)$ \\
\hline \# Jobs & \multicolumn{2}{|c|}{139,739} & \multicolumn{2}{|c|}{153,695} \\
\hline \# Observations & \multicolumn{2}{|c|}{$1,986,332$} & \multicolumn{2}{|c|}{$2,219,152$} \\
\hline
\end{tabular}

Standard errors in parentheses.

Thus far, we have shown that high-educated workers experience faster wage growth than less-educated workers when working for the same employer. High-educated males who move directly from one job to another also gain more than their less-educated counterparts. Wages decline for females and males moving through unemployment, but the loss is smaller for those with less education.

Overall, more educated individuals experience higher average wage growth over the course of one year. While these purely descriptive statistics show that there is positive correlation between wage growth and educational attainment, the source of this wage growth is not determined. We now turn to the empirical model developed in the previous section to obtain estimates of the underlying parameters.

\section{Returns to Experience, Tenure, and Improved Job Match}

In this section, we estimate the returns to tenure, general and sector-specific experience, and job match that are the underlying processes generating the within- and between-job 
wage growth shown in Tables 3 and 4 . Within-job wage changes are affected by returns to tenure, sector-specific experience, and general experience. Flatter within-job profiles of less-educated workers, therefore, may reflect lower returns to any one of these components. A direct consequence of lower investments in firm-specific investments (as reflected in lower returns to tenure) would be that less-educated workers would have less to lose from leaving a job either voluntarily or involuntarily. Alternatively, if the flatter profiles reflect lower returns to general or sector-specific experience, then this implies that less-educated workers accumulate fewer of these skills.

We use the methodology developed earlier to estimate the key underlying parameters in equations 10a and 12. Two-digit industry codes are used to define sectors in the results presented below. ${ }^{32}$ The key covariates are tenure in the previous job, $\widetilde{T}$, and the change in sector-specific experience when moving to a job in a different sector, $\tilde{S}$. We follow Parent (2000) by using continuous months of sector experience to measure $\tilde{S}^{33}$ We also include a set of year dummies and monthly, state-specific non-employment rates to take account of secular and cyclical changes that may affect wage growth. Part-time status is included and allowed to have a different effect for those who change hours worked within the same firm and those who change to or from part-time when moving between jobs.

Tables 6 and 7 present the estimated parameters for females and males, respectively. ${ }^{34}$ Column 1 constrains coefficients to be the same across all levels of educational attainment. The remaining columns show estimated parameters for high school dropouts, high school graduates, and college graduates. The bottom row tests for equality of coefficients across education groups.

Column 1, which constrains coefficients to be the same across all education groups, shows the standard concave experience profile and positive returns to both tenure and sector experience. All coefficients are statistically significant at conventional levels for females, and all but tenure are significant for males. Note that the coefficients on sector experience are larger than the coefficients on tenure for both females (.005 versus .003) and males (.005 versus .000). This is consistent with much of the recent literature that argues that returns to firm-specific tenure largely reflect returns to the sector-specific skills gained in that job. Sector-specific and general experience have roughly equal impact on within-job wage growth at the start of the working lives of females (.005 per month), but general experience has a substantially greater impact than sector experience on the wages of young males (.012 versus $.005)$.

The next panel shows that females improve their job match by 4.6 percent when moving directly from one job to another. If they experience a spell of non-employment between jobs, then there is a small but statistically insignificant decline in the job match component. Males gain 5.9 percent when moving directly from one job to the next, but lose 4.6 percent when moving through non-employment.

\footnotetext{
${ }^{32}$ The results are similar whether one-, two-, or three-digit sector categories are used. Additionally, we find similar results when using occupation to define the employment sector.

${ }^{33}$ Parent (2000) finds that using continuous years in an industry gives results that are similar to those that include prior non-continuous spells in the industry to measure $\tilde{S}$. This holds for the PSID as well as the NLSY where Parent observes the full job history. Like Parent's analysis of the PSID, we are limited to industry-specific experience observed in the panel.

${ }^{34}$ The estimated standard errors take into account the panel nature of the data.
} 
Table 6: Returns to Tenure, Experience, and Job Match, females

Table 6: Returns to Tenure, Experience, and Job Match, females (between-job wage changes with industry)

\begin{tabular}{|c|c|c|c|c|}
\hline & \multirow{2}{*}{$\begin{array}{c}\text { Constrained } \\
A L L\end{array}$} & \multicolumn{3}{|c|}{ Categorical Education } \\
\hline & & LTHS & HS Grad & College Grad \\
\hline Wage Equation: & (1) & (2) & (3) & (4) \\
\hline \multirow[t]{2}{*}{ Experience } & $0.005^{* *}$ & 0.004 & 0.002 & $0.013^{* *}$ \\
\hline & $(0.002)$ & $(0.006)$ & $(0.003)$ & $(0.006)$ \\
\hline \multirow[t]{2}{*}{ Experience $^{2}$} & $-0.039^{* * *}$ & $-0.028^{*}$ & $-0.027^{* * *}$ & $-0.074^{* * *}$ \\
\hline & $(0.006)$ & $(0.015)$ & $(0.007)$ & $(0.018)$ \\
\hline \multirow[t]{2}{*}{ Tenure } & $0.003^{* *}$ & 0.001 & $0.002 *$ & 0.005 \\
\hline & $(0.001)$ & $(0.002)$ & $(0.001)$ & $(0.004)$ \\
\hline \multirow[t]{2}{*}{ Sector Experience } & $0.005^{* * *}$ & 0.003 & $0.005^{* * *}$ & 0.006 \\
\hline & $(0.001)$ & $(0.002)$ & $(0.001)$ & $(0.003)$ \\
\hline \multicolumn{5}{|l|}{ Job Match: } \\
\hline \multirow[t]{2}{*}{ Match Through Unemployment } & -0.006 & 0.016 & -0.014 & -0.017 \\
\hline & $(0.009)$ & $(0.014)$ & $(0.010)$ & $(0.044)$ \\
\hline \multirow[t]{2}{*}{ Job-to-Job } & $0.046^{* * *}$ & $0.027^{*}$ & $0.042^{* * *}$ & $0.070^{* * *}$ \\
\hline & $(0.007)$ & $(0.016)$ & $(0.007)$ & $(0.022)$ \\
\hline \multirow[t]{2}{*}{ Previous Tenure } & -0.001 & -0.002 & -0.001 & 0.000 \\
\hline & $(0.001)$ & $(0.002)$ & $(0.001)$ & $(0.005)$ \\
\hline \multirow[t]{2}{*}{ Previous Sector Experience } & $0.006^{* * *}$ & $0.007^{* *}$ & $0.006^{* * *}$ & 0.004 \\
\hline & $(0.001)$ & $(0.002)$ & $(0.001)$ & $(0.004)$ \\
\hline \multicolumn{5}{|l|}{ Tests of Interactions } \\
\hline F (All Interactions $=0)$ & ----- & 4.04 & 2.72 & 4.95 \\
\hline Probability & ----- & 0.00 & 0.00 & 0.00 \\
\hline \# Individuals & 74,922 & 74,922 & 74,922 & 74,922 \\
\hline \# Observations & $1,608,831$ & $1,608,831$ & $1,608,831$ & $1,608,831$ \\
\hline$R^{2}$ & 0.0016 & 0.0013 & 0.0015 & 0.0036 \\
\hline
\end{tabular}

NOTES:

Robust standard errors in parentheses. (* significant at 10\%; ** significant at $5 \% ; * * *$ significant at $1 \%$ )

Experience $^{2}$ multiplied by $100^{2}$.

Additional covariates include part-time status, unemployment rate, and year dummies. 
Table 7: Returns to Tenure, Experience, and Job Match, males

Table 7: Returns to Tenure, Experience, and Job Match, males (between-job wage changes with industry)

\begin{tabular}{|c|c|c|c|c|}
\hline & & \multicolumn{3}{|c|}{ Categorical Education } \\
\hline & $A L L$ & LTHS & HS Grad & College Grad \\
\hline Wage Equation: & (1) & (2) & (3) & (4) \\
\hline \multirow[t]{2}{*}{ Experience } & $0.012^{* * *}$ & $0.016^{* *}$ & $0.005^{*}$ & $0.028^{* * *}$ \\
\hline & $(0.002)$ & $(0.006)$ & $(0.003)$ & $(0.006)$ \\
\hline \multirow[t]{2}{*}{ Experience $^{2}$} & $-0.063^{* * *}$ & $-0.023^{*}$ & $-0.067^{* * *}$ & $-0.091^{* * *}$ \\
\hline & $(0.006)$ & $(0.013)$ & $(0.007)$ & $(0.016)$ \\
\hline \multirow[t]{2}{*}{ Tenure } & 0.000 & -0.002 & 0.001 & -0.001 \\
\hline & $(0.001)$ & $(0.002)$ & $(0.001)$ & $(0.004)$ \\
\hline \multirow[t]{2}{*}{ Sector Experience } & $0.005^{* * *}$ & 0.002 & $0.006^{* * *}$ & 0.002 \\
\hline & $(0.001)$ & $(0.003)$ & $(0.001)$ & $(0.004)$ \\
\hline \multicolumn{5}{|l|}{ Job Match: } \\
\hline \multirow[t]{2}{*}{ Match Through Unemployment } & $-0.046^{* * *}$ & $-0.050^{* * *}$ & $-0.032^{* *}$ & $-0.143^{* * *}$ \\
\hline & $(0.010)$ & $(0.018)$ & $(0.012)$ & $(0.053)$ \\
\hline \multirow[t]{2}{*}{ Job-to-Job } & $0.059^{* * *}$ & $0.039^{* * *}$ & $0.057^{* * *}$ & $0.097^{* * *}$ \\
\hline & $(0.006)$ & $(0.013)$ & $(0.007)$ & $(0.022)$ \\
\hline \multirow[t]{2}{*}{ Previous Tenure } & $-0.003^{* *}$ & $-0.005^{* *}$ & -0.002 & -0.006 \\
\hline & $(0.001)$ & $(0.002)$ & $(0.001)$ & $(0.005)$ \\
\hline \multirow[t]{2}{*}{ Previous Sector Experience } & $0.004^{* * *}$ & 0.002 & $0.005^{* * *}$ & 0.002 \\
\hline & $(0.001)$ & $(0.003)$ & $(0.001)$ & $(0.005)$ \\
\hline \multicolumn{5}{|l|}{ Tests of Interactions } \\
\hline F (All Interactions $=0)$ & ----- & 6.14 & 2.49 & 7.43 \\
\hline Probability & ----- & 0.00 & 0.01 & 0.00 \\
\hline \# Individuals & 80,945 & 80,945 & 80,945 & 80,945 \\
\hline \# Observations & $1,813,315$ & $1,813,315$ & $1,813,315$ & $1,813,315$ \\
\hline$R^{2}$ & 0.0023 & 0.0015 & 0.0020 & 0.0079 \\
\hline
\end{tabular}

NOTES:

Robust standard errors in parentheses. (* significant at 10\%; ** significant at $5 \%$; *** significant at $1 \%$ )

Experience $^{2}$ divided by $100^{2}$.

Additional covariates include part-time status, unemployment rate, and year dummies. 
The remaining columns show the importance of allowing the parameters to vary by education. The null hypothesis that the estimated coefficients are equal across education groups is strongly rejected at conventional levels (see bottom row). The coefficients on experience, tenure, and sector experience for females with less than a high school education are all small and statistically insignificant, which is consistent with their small within-job wage growth. The higher within-job wage growth for female high school graduates largely reflects their higher returns to sector experience, which is statistically significant. College graduates, who have the highest within-job wage growth, benefit primarily from higher returns to general experience, especially early in their careers.

For males the differences across education groups are remarkably similar to those for females. Returns to tenure and sector are small and insignificant for male high school dropouts, though returns to general experience are statistically significant. The higher within-job wage growth for male high school graduates largely reflects their higher returns to sector-specific experience. Just like females, male college graduates also benefit largely from high returns to general experience early in their careers.

Turning to educational differences in the job match component again reveals similar patterns for males and females. Job-to-job transitions reflect improvements in the job match component for all education groups, but the improvements are larger for those with more education. Female high school dropouts experience a 2.7 percent gain in the job match component when going directly from one job to the next. High school graduates and college graduates gain 4.2 and 7.0 percent, respectively. The corresponding gains for males are 3.9, 5.7 and 9.7 , respectively.

While more-educated males and females have larger increases in their job match components when moving directly from one job to another, they do not have a similar advantage when experiencing an intervening spell of non-employment. Male high school dropouts experience a 5.0 percent decline in the match component, which is larger than the 3.2 percent decline for high school graduates, but smaller than the 14.3 percent decline for college graduates. The change in the match component for females who experience an intervening spell of non-employ are not significantly different from zero for any of the education groups.

In summary, Tables 6 and 7 show that higher returns to general experience and larger improvements in the job match component when going directly from one job to the next are the primary determinants of the high wage growth among college educated workers. While improved job match is smaller for less-educated workers, the other sources of wage growth are also small. As a result, wage growth among less-educated workers largely reflects improvements in the job match.

\section{Conclusions}

We started this paper by asking whether returns to general experience, tenure, sector experience, and improved job match differ by educational attainment. This question has not only been asked repeatedly in the human capital literature, but is also directly relevant to the recent policy debate over the gains to work for welfare recipients.

We developed a conceptual framework that allows us to separately identify the returns to tenure, sector experience, general experience, and job match. This framework is based on 
a simple job search model that implies that returns to job match depend on whether the job transition is interrupted by an intervening spell of non-employment between jobs. This is sufficient to identify all parameters.

We have shown that log earnings profiles are not parallel. Both within-job wage growth and between-job wage growth are higher for more-educated workers. This is true for both males and females. The high within-job wage growth of college graduates largely reflects higher returns to general experience, while the within-job wage growth of high school graduates primarily reflects large returns to sector-specific experience. Returns to tenure are small and insignificant for all but female high school graduates. Our results indicate that the wage growth of less-educated workers found in cross sectional regressions largely reflects improved job match, not returns to tenure, sector-specific experience, or general experience.

Our results imply very different returns to human capital investments across educational groups. The low returns for the less-educated provide little incentive to invest in job-specific, sector-specific, or general human capital. As Heckman et al. (1998) stress, this implies that the gap in observed earnings early in life understates the gap in earnings capacity. Our results are also consistent with the observed high turnover rates of less-educated workers whose wage growth comes largely from improved job match. 


\section{References}

Altonji, J. G. and R. A. Shakotko (1987, Jul). Do Wages Rise with Job Seniority? Review of Economic Studies 54(3), 437-59.

Altonji, J. G. and N. Williams (1997, April). Do Wages Rise with Job Seniority? A Reassessment, Volume 6010 of NBER Working Paper Series. National Bureau of Economic Research, Inc.

Altonji, J. G. and N. Williams (1998). The Effects of Labor Market Experience, Job Seniority, and Job Mobility on Wage Growth. In S. W. Polachek (Ed.), Research in Labor Economics, Volume 17, pp. 233-76. Stamford, CT: JAI Press.

Ben-Porath, Y. (1967, August). The Production of Human Capital and the Life Cycle of Earnings. Journal of Political Economy 75(4), 352-65.

Brown, J. N. and A. Light (1992, July). Interpreting Panel Data on Job Tenure. Journal of Labor Economics 10(3), 219-57.

Burdett, K. (1978, March). A Theory of Employee Job Search and Quit Rates. American Economic Review 68(1), 212-20.

Burtless, G. (1995). Employment Prospects of Welfare Recipients. In D. S. Nightingale and R. H. Haveman (Eds.), The Work Alternative: Welfare Reform and the Realities of the Job Market, Chapter 4. Washington, DC: Urban Institute Press.

Card, D. and J. E. DiNardo (2002, Oct). Skill-Biased Technological Change and Rising Wage Inequality: Some Problems and Puzzles. Journal of Labor Economics 20(4), 733-83.

Card, D., C. Michalopoulos, and P. K. Robins (1999, November). Measuring Wage Growth Among Former Welfare Recipients. Number 20 in Center for Labor Economics Working Paper Series. Berkeley, CA: University of California.

Dustmann, C. and C. Meghir (2005, jan). Wages, experience and seniority. Review of Economic Studies 72(1), 77-108.

Gladden, T. and C. Taber (2000). Wage Progression Among Less Skilled Workers. pp. 160-92.

Gueron, J. M. and E. Pauly (1991). From Welfare to Work. New York, NY: Russell Sage Foundation.

Haider, S. (2001, October). Earnings instability and earnings inequality of males in the united states: 1967-1991. Journal of Labor Economics 19(4), 799-836.

Heckman, J. J., L. Lochner, and C. Taber (1998, January). Explaining Rising Wage Inequality: Explorations with a Dynamic General Equilibrium Model of Labor Earnings with Heterogeneous Agents. Review of Economic Dynamics 1(1), 1-58. 
Heckman, J. J., L. J. Lochner, and P. E. Todd (2003, May). Fifty Years of Mincer Earnings Regressions. Number 9732 in NBER Working Paper Series. National Bureau of Economic Research, Inc.

Kambourov, G. and I. Manovskii (2005, December). Occupational Specificity on Human Capital. University of Toronto.

Lemieux, T. (2003). The 'Mincer Equation' Thirty Years After Schooling, Experience, and Earnings. Number 62 in Center for Labor Economics Working Paper Series. Berkeley, CA: University of California.

Light, A. and K. McGarry (1998, May). Job Change Patterns and the Wages of Young Men. Review of Economics and Statistics 80(2), 276-86.

Mincer, J. (1974). Schooling, Experience, and Earnings. New York, NY: National Bureau of Economic Research, Inc.

Mincer, J. and B. Jovanovic (1981). Labor Mobility and Wages. In S. Rosen (Ed.), Studies in Labor Markets, pp. 21-63. Chicago, IL: University of Chicago Press.

Moffitt, R. and A. Rangarajan (1991). The Economics of Social Security, Chapter The Effect of Transfer Programmes on Work Effort and Human Capital Formation: Evidence from the U.S. Oxford: Oxford University Press.

Murphy, K. M. and F. Welch (1992, Feb). The Structure of Wages. The Quarterly Journal of Economics 107(1), 285-326.

Neal, D. (1995, October). Industry-Specific Human Capital: Evidence from Displaced Workers. Journal of Labor Economics 13(4), 653-677.

Parent, D. (2000, April). Industry-specific capital and the wage profile: Evidence from the national longitudinal survey of youth and the panel study of income dynamics. Jounal of Labor Economics 18(2).

Pavan, R. (2005, December). Career Choice and Wage Growth. University of Rochester.

Topel, R. H. (1991, February). Specific Capital, Mobility, and Wages: Wages Rise with Job Seniority. Journal of Political Economy 99(1), 145-76. 